\title{
Hard Corporate Governance Law in a Soft Law Jurisdiction
}

\author{
Bryane Michael, University of Hong Kong and \\ Say Goo, University of Hong Kong
}

1 November 2016

\section{Contents}

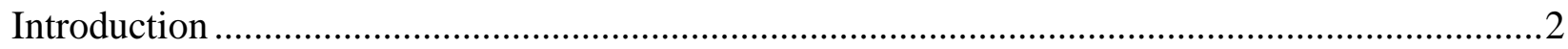

An Overview of the Corporate Governance of China's Companies .................................................... 4

Increasing Participation as the Driver of Corporate Governance Regulatory Change ....................10

Updating China's Code of Corporate Governance and Other Regulations ....................................16

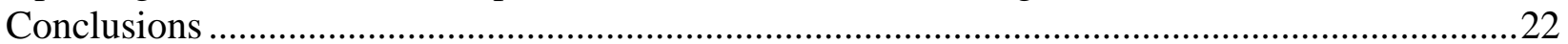

\begin{abstract}
China’s fuzzy corporate governance rules (whether hard or soft) do not help company managers, government officials and others coordinate and cooperate - the raison d'etre for corporate governance rules. In a corporate system dominated by personal relationships and rules, clarity and specificity - even in principles-based corporate governance - serve Chinese corporations far better than passing rules into law or visa versa. We show how existing rules (whether soft, lard, mandatory, voluntary, etc.) harm corporate interests. We illustrate how adding clarity makes the hard/soft law distinction moot. "Coordinatable" rules which help new Chinese participants in corporate governance understand government expectations, follow these understandings, and seek recourse through existing mechanisms, will serve Chinese companies better than best practice or rules of thumb like having a certain proportion of independent directors, internal auditors, etc.
\end{abstract}

Keywords: Chinese corporate governance, Code of Corporate Governance, coordinatability, hard law, soft law.

JEL codes: G34, N25, M14

Acknowledgement: We gratefully acknowledge the Hong Kong Theme-Based Research Grant Scheme for support. Faults with the paper belong to us alone. Errors of course remain our own. 


\title{
Hard Corporate Governance Law in a Soft Law Jurisdiction
}

\author{
Bryane Michael, University of Hong Kong and \\ Say Goo, University of Hong Kong
}

\section{Introduction}

Is it time to move from soft law to hard law in strengthening corporate governance rules? Academics have theorised for a long about the role of soft law in improving corporate governance - with some announcing that the time has come to adopt hard legal provisions in places like China. ${ }^{1}$ Never mind that the previous reforms to China's company and other law had not demonstrably had revolutionary effects. ${ }^{2}$ Such reform now simply consists of passing into hard law a laundry list of reforms - requiring "independent directors, employee representatives, more clearly defined directors' duties, especially their duties toward stakeholders, mandatory information disclosure of corporate social responsibility (“CSR”) issues, legitimacy of crosslisting, effective auditing, and the appointment of independent external auditors." ${ }^{3}$ Many scholars think that hard law forcing corporate accountability should suffice in lieu of prescriptive requirements placed on companies. ${ }^{4}$ Yet, with the Communist Party has the ultimate engine of accountability, to what extent do Chinese firms still need to rely on informal soft law dictates and expectations of the Party as opposed to hard law used by private actors and public authorities? ${ }^{5}$

Our thesis argues that the time has come for "coordinatable" rules which help shape the expectations of stakeholders in Chinese companies - clear, hard law rules enforced through existing informal mechanisms rather than courts. Following Clarke's landmark article, new rules should comprise 'law without order' - concrete orders with consequences spelled out and enforced by the regulatory agencies. ${ }^{6}$ We use Hong Kong's rules as a contrast when appropriate showing how more specific and concrete rules facilitate the adoption and enforcement of corporate governance rules. The first part of our paper "proves" the failure of existing corporate governance rules, illustrating the need for clearer, more specific rules for market actors (even before considering the law enforcement agencies and courts charged with enforcing them). The second section shows how trends in increasingly public/popular participation in Chinese corporate life (as owners, suppliers, investors and so forth), have changed the corporate governance rules Chinese corporates need. We illustrate this change through transitions in state-

\footnotetext{
${ }^{1}$ Liu, Jun-hai, Globalisation of Corporate Governance Depends on Both Soft Law and Hard Law, Corporate Governance Codes for the 21st Century, In du Plessis, Jean and Chee-Keong Low, Corporate Governance Codes for the 21st Century: International Perspectives and Critical Perspectives, 2017, at pp. 275-294.

${ }^{2}$ Feinerman, James, New Hope for Corporate Governance in China? China Quarterly, 2007, pp. 590-619, available online.

${ }^{3}$ Zhao, Jing-chen, Promoting a More Efficient Corporate Governance Model in Emerging Markets Through Corporate Law, Washington University Global Studies Law Review 15, 2016, at p. 447, 2016, available online.

${ }^{4}$ Kevin Jackson, Global Corporate Governance: Soft Law and Reputational Accountability, Brooklyn Journal of International Law 35, 2010, available online.

${ }^{5}$ Wang, Jiang-yu, The Political Logic of Corporate Governance in China's State-owned Enterprises, Cornell International Law Journal 35, 2014, available online.

${ }^{6}$ Clarke actually points to the ineffectiveness of China's law without order approach to corporate governance. Regulatory agencies fail to enforce corporate governance rules. As we counter in this paper, clearer hard rules would significantly help such enforcement. Clarke, Donald, Law without Order in Chinese Corporate Governance Institutions, Northwestern Journal of International Law \& Business, 30(1), 2010, available online.
} 
owned enterprise governance and in off-shore backdoor listings. Comfort with ambiguous rules has helped fuel the reverse merger trends which have emerged as both consequence and result of vague corporate governance rules. Ditto with state-owned enterprises, which adapt to remain relevant to new stakeholders with new interests. The third section directly discusses China's Code of Corporate Governance - illustrating the fuzziness of rules partly by comparing them to more concrete alternatives from Hong Kong. Harder law would not necessarily enable private parties or even government agencies trying to enforce them (under conditions where they have few if any de jure or de facto property rights). ${ }^{7}$ Instead, harder law provisions would, at least, make clear what businesses and other parties to corporate governance rules should do. ${ }^{8}$ The final section concludes by arguing, in a context like China, that hard law serves as a coordination mechanism rather than a means of making and enforcing contracts.

We should start this paper with a few caveats. First, to weave theory and empirics into our paper succinctly, we forgo the usual literature review. In line with the new comparative corporate governance literature, we engage with theory through our presentation of the relevant data and law - often in footnotes when the point addresses something non-critical. ${ }^{9}$ We save space, more directly link theory to facts, and avoid building the grand narratives which have plagued our disciple up to the present time. ${ }^{10}$ Second, we do not provide a complete survey or overview of Chinese corporate law or law related to corporate governance issues. Critics might argue that we pick-and-choose our topics and instruments to analyse. We do this because of this journal's space constraints - as well as to illustrate the broader point without overwhelming the reader. Third, we paint corporate governance law into a dichotomous landscape of soft and hard - with anything abstract or vague lying in the realm of soft. We accept that any principles-based rules represent 'hard' and 'soft' law working at the same time - making such labels facile. ${ }^{11}$ Yet, by keeping with the tradition of hard law as specific, concrete, and well-understood by all parties, we basically categorise 'hard' and 'soft' by ends rather than means. Hard law helps corporate

\footnotetext{
${ }^{7}$ As Donaldson and Preston clearly state the "normative base of the [stakeholder] theory—which includes the modem theory of property rights - is fundamental." While "stakeholders are persons or groups with legitimate interests in procedural and/or substantive aspects of corporate activity," Chinese persons have far fewer rights attached to these interests than in the West. See Donaldson, Thomas and Lee Preston, The Stakeholder Theory of the Corporation: Concepts, Evidence, and Implications, Academy of Management Review 20(1), 1995.

${ }^{8}$ The contracting view of corporate governance has become so canonical to our conception of corporate governance that we no longer even doubt the role of corporate governance rules as an 'extra set' of contractual obligations - in the public interest so as to increase the effectiveness of contractual provisions made between parties. Yet, before such a consensus emerged, many argued for corporate governance rules as facilitating common understanding of how companies should act vis-a-vis other stakeholders. See Macey, Jonathan, Corporate Law and Corporate Governance: A Contractual Perspective, Journal of Corporation Law 18, 1993.

${ }^{9}$ While authors like Garcia-Castro and colleagues would argue that different countries have their own sets of characteristics (and thus defy grand unifying theories), critical authors like Mason and O’Mahony describe the problems of traditional corporate governance research, without using all the terms from critical sociology which would challenge even the most die-hard jargon fan. See Roberto, Garcia-Castro, Ruth Aguilera, and Miguel A. Arino, Bundles of Firm Corporate Governance Practices: A Fuzzy Set Analysis, Corporate Governance 21(4), 2013. See also Mason, Michael, and Joan O'Mahony. Post-Traditional Corporate Governance. Journal of Corporate Citizenship Autumn, 2008, available online.

${ }^{10}$ For a discussion, see Wells, Harwell, The Birth of Corporate Governance, Seattle University Law Review 33(1), 2010, available online.

${ }^{11}$ Laurence Cunningham, A Prescription to Retire the Rhetoric of Principles-Based Systems in Corporate Law, Securities Regulation, and Accounting, Vanderbilt Law Review 60, 2007.
} 
stakeholders coordinate, form expectations, and bargain. Soft law (by definition) fails to achieve these goals.

\section{An Overview of the Corporate Governance of China's Companies}

The data show significant shortcomings in the Chinese Mainland's companies' corporate governance. ${ }^{12}$ Figure 1 shows the gap between standard indices of the quality of China's corporate governance, compared with other jurisdictions for easy reference. ${ }^{13}$ We show these crude data only a lead in to our discussion - and not as samples used to accurate estimate levels of corporate governance. ${ }^{14}$ The quality of the Mainland's corporate governance remains low despite significant reform over the last $15+$ years. ${ }^{15}$ Both the rules themselves, as well as their enforcement, lag behind jurisdictions like Hong Kong and/or Singapore. Figure 2 shows China's companies' corporate governance scores by each of the dimensions identified in the OECD's Corporate Governance Principles. ${ }^{16}$ The worst companies score lowly on giving the firms' stakeholders and the supervisory board a say in corporate governance. Even the worst of the batch score reasonably well on information disclosure and transparency. Chinese corporate governance seems to focus on shareholders - with companies earning the highest scores among the set for fairness to shareholders. Yet, none of these measures look at the clarity of these rules. ${ }^{17}$ The measurements themselves might be "hard" in the sense of being specific and clear (such as the extent to which audit committees exist and have certain memberships). Yet, the rules governing these outcomes usually exhibit large variability in the extent to which they improve specific, rather than general, requirements. Following Dr. Love, Corporate governance indicators we show reflect the vague, subjective outcomes they seek to measure and promote. ${ }^{18}$ If true, corporate governance rules and their measurement can not existentially comprise "hard"

\footnotetext{
${ }^{12}$ Throughout this paper, we try to refer to China (excluding Hong Kong and Macao) as the Mainland. We follow this Hong Kong convention, as most of our comparisons deal with Hong Kong versus the Mainland. Inadvertent slips, calling the Mainland "China" or referring to Hong Kong as a country rather than a jurisdiction, reflect our haste rather than some deep-seated political views.

${ }^{13}$ See Asian Corporate Governance Association, CG Watch 2014 - Market Rankings, Asian Corporate Governance Association Presentation, 2015, available online.

${ }^{14}$ Most statistical work goes toward estimating some "true" level of a variable - like corporate governance (however defined). We use these data instead to give overall impressions, without trying to find error bands, entropy or other exact measurements of these data. As Schnyder has pointed out, even "objective" measures of corporate governance (like measuring the number of independent directors), rather than subjective impressions, miss important interactions. Thus, we do not wish the reader to put too much stock in exact values of these variables. See Schnyder, Gerhard, Measuring Corporate Governance: Lessons from the ‘Bundles Approach', University of Cambridge Centre for Business Research Working Paper No. 438, 2012, available online.

${ }^{15}$ The summary statistics we show here can not compare with the deep insights that in-depth scholarly analysis of Chinese corporate governance provides. See Kang, Yong, Lu Shi, and Elizabeth Brown, Chinese Corporate Governance: History and Institutional Framework, Rand Corporation Technical Report 618, 2008, available online.

${ }^{16}$ For the description of the questions used to assess each area, see OECD, G20/OECD Principles of Corporate Governance, 2015, available online. For the data, see Protiviti, Corporate Governance Assessment Summary Report on the Top 100 Chinese Listed Companies for 2012, 2013, available online. For a summary of the OECD's questions (put into convenient tabular Q\&A form), see Tong, Lu, Ji-yin Zhong, and Jie Kong, Corporate Governance Assessment on the Top 100 Chinese Listed Companies, 2006, available online.

${ }^{17}$ For one such review of these estimates, see Khanchel, Imen, Corporate Governance: Measurement and Determinant analysis, Managerial Auditing Journal 22(8), 2007, available online.

${ }^{18}$ Love, Inessa, Corporate Governance and Performance around the World: What We Know and What We Don't. World Bank Research Observer 26(1), 2011.
} 
instructions signalling clear expectations about the way the government or management want other stakeholders to behave. ${ }^{19}$

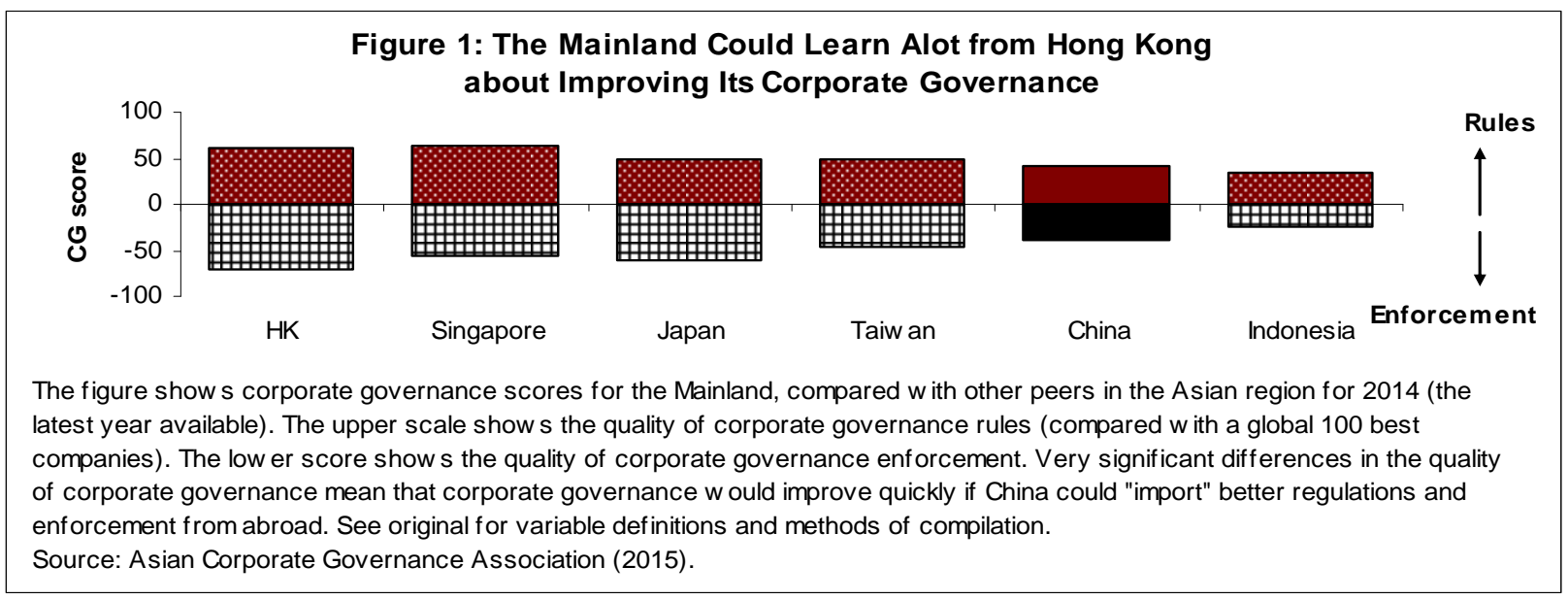

Figure 2: Chinese Corporate Governance Only at 37\% of the World's Highest Standards

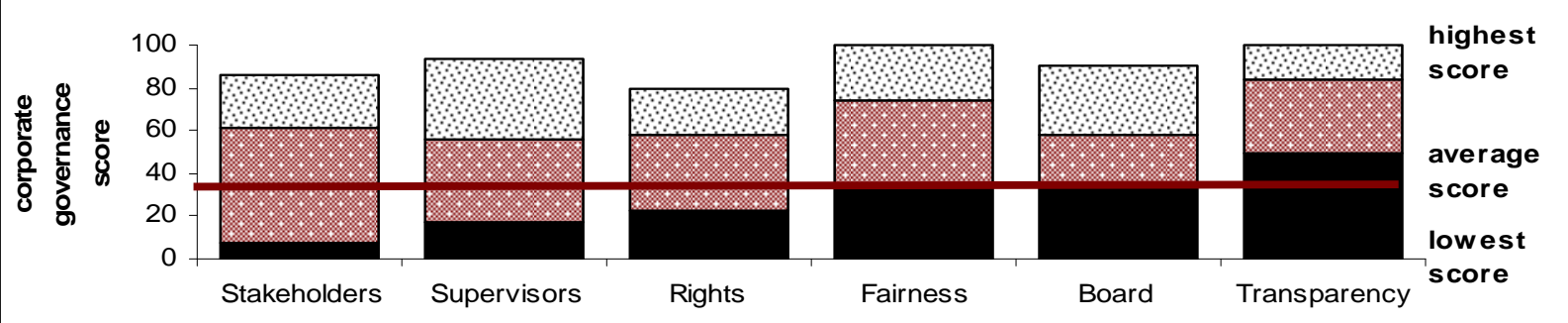

The figure shows the corporate governance scores among the largest 100 listed Chinese companies for the areas of corporate governance mentioned in the figure. The red line shows the average across categories. The black bars show the low est score (for stakeholder participation for example, the low est scoring company only earned 7 out of 100 points).

Source: Protiviti (2013).

The variation in corporate governance scores among Chinese firms represents a far more disconcerting signal about corporate governance rules in the Middle Kingdom than the low average scores earned by these companies. Chinese companies score badly on each dimension of corporate governance - with an average corporate governance score of around $37 \%$ out of the 100\% earned by companies completely implementing the OECD Principles (as shown above in Figure 2). Yet, Figure 3 shows the very large variation in corporate governance practices and performances among Chinese firms. Corporate governance scores for various companies in a range of industries can vary from $30 \%$ to $80 \%$ of best practice. The trend shows a general improvement in corporate governance practices in recent years. Yet, the large variation in these scores, both across time and across firms, indicates that China's corporate governance policies are "out of control" (in the statistical sense of the word) ${ }^{20}$ In other words, because of the large

\footnotetext{
${ }^{19}$ Econometric work has already tried to gauge the truth of this assertion. See Franz, Randal and Dong-hun Lee, Global Institutions of Business? Comparing Role-of-Business Expectations in [the, sic] USA, South Korea, Hong Kong and Singapore. In Capaldi, Nicolas, Samuel Idowu, and Rene Schmidpeter, Eds., Dimensional Corporate Governance: An Inclusive Approach, Springer Publishing, 2017.

${ }^{20}$ Out of control processes refer to processes which exhibit wide variation, making predicting them (and thus regulating them) more difficult. See Harp, Nancy, Mark Myring, and Rebecca Shortridge, Do Variations in the
} 
variation in corporate governance practices among Chinese firms, policymakers can not adopt policies focused on improving such governance until senior managers bring these companies' governance practices "under control." ${ }^{21}$ Because of its clarity, only hard law can achieve such control - if drafting such law is even epistemologically possible and understandable. ${ }^{22}$

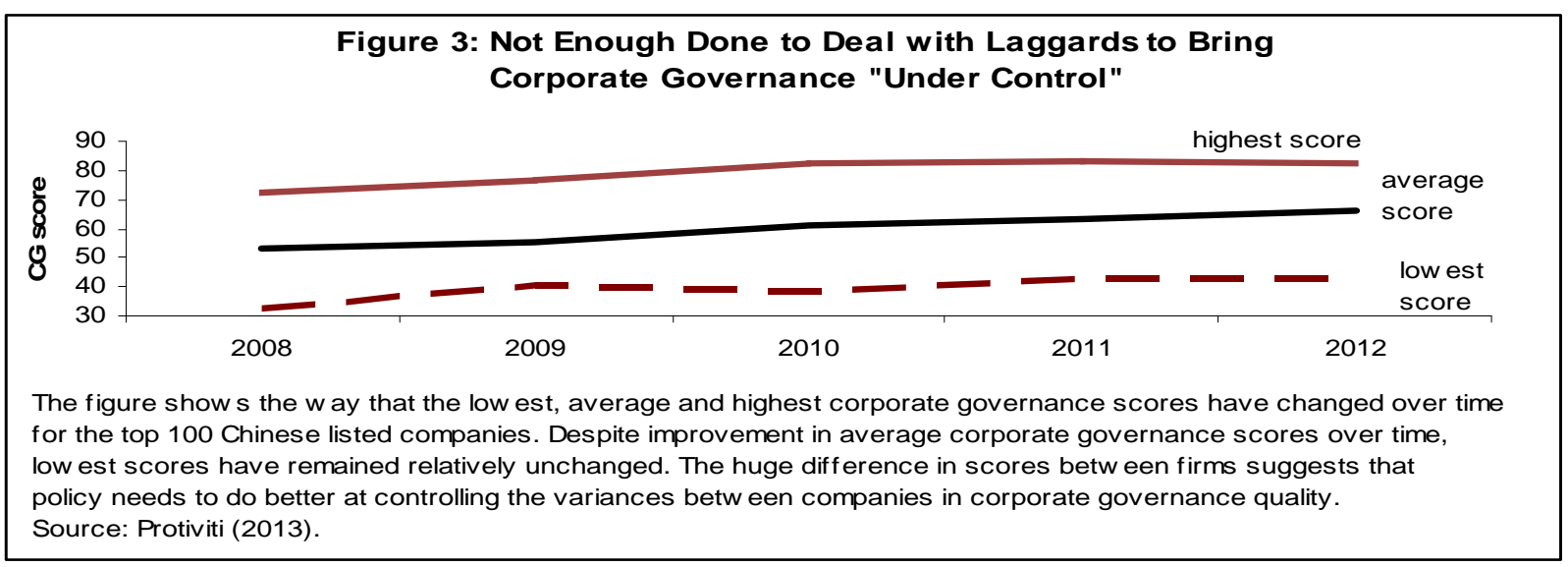

Variation in corporate governance practices across industries also points to the need for more coordinated corporate governance-related rulemaking. As shown in Figure 4, financial services firms score a reasonably good $72 \%$ out of $100 \%$. Companies in the mining, manufacturing and other sectors however, only score between $60 \%$ and $65 \%$ out of $100 \%$. The government's post2008 extra corporate governance related regulations clearly explain why the financial sector scores best. ${ }^{23}$ The financial sectors experience may suggest that increased government regulation and enforcement of corporate governance rules can bring these scores "under control" and raise standards across the board. Yet, the specificity of "hard law" financial sector corporate

Strength of Corporate Governance Still Matter? A Comparison of the Pre- and Post-Regulation Environment, Journal of Business Ethics 122(3), 2014, available online. See also Fan, Steve and Linda Yu, Variation in Corporate Governance and Firm Valuation - an International Study, International Review of Finance (Early View), 2016, available online.

${ }^{21}$ Besides being a truism in the Six Sigma literature, even legal scholars have made the case for ensuring such control before engaging in reform. For example, see Pacces, Alessio, Rethinking Corporate Governance: The Law and Economics of Control Powers, Routledge, 2012.

${ }^{22}$ Authors like Zadkovich mistakenly argue that the inflexibility of hard and precise mandatory requirements discourages companies and regulators from using them more broadly. Clearly, such a view confuses legal/regulatory clarity with enforeability. No a priori reason exists to require mandatory rules to state clear, well-defined practices. See Zodkovich, John, Mandatory Requirements, Voluntary Rules And 'Please Explain': A Corporate Governance Quadmire, Deakin Law Review 12(2), 2007, available online.

${ }^{23}$ In China, as in other jurisdictions, regulators passed a number of corporate governance and other regulations aimed at responding to the global financial crisis of 2007-2008, as well as strengthening financial institutions in the future. Interestingly, Erkens and co-authors find that good corporate governance practices exacerbated the effect of the financial crisis on financial firms around the world (including China). As such, policymakers can not rely on simply improving corporate governance as a means of promoting financial stability. They will need to draft rules that reduce risk-taking behaviour approved of by institutional investors and independent board members. See Erkens, David, Ming-Yi Hung, and Pedro Matos, Corporate governance in the 2007-2008 financial crisis: Evidence from financial institutions worldwide, Journal of Corporate Finance 18, 2012, available online. 
governance regulations - as opposed to those in other sectors - might well explain these results, better than simply the fact they represent hard law. ${ }^{24}$

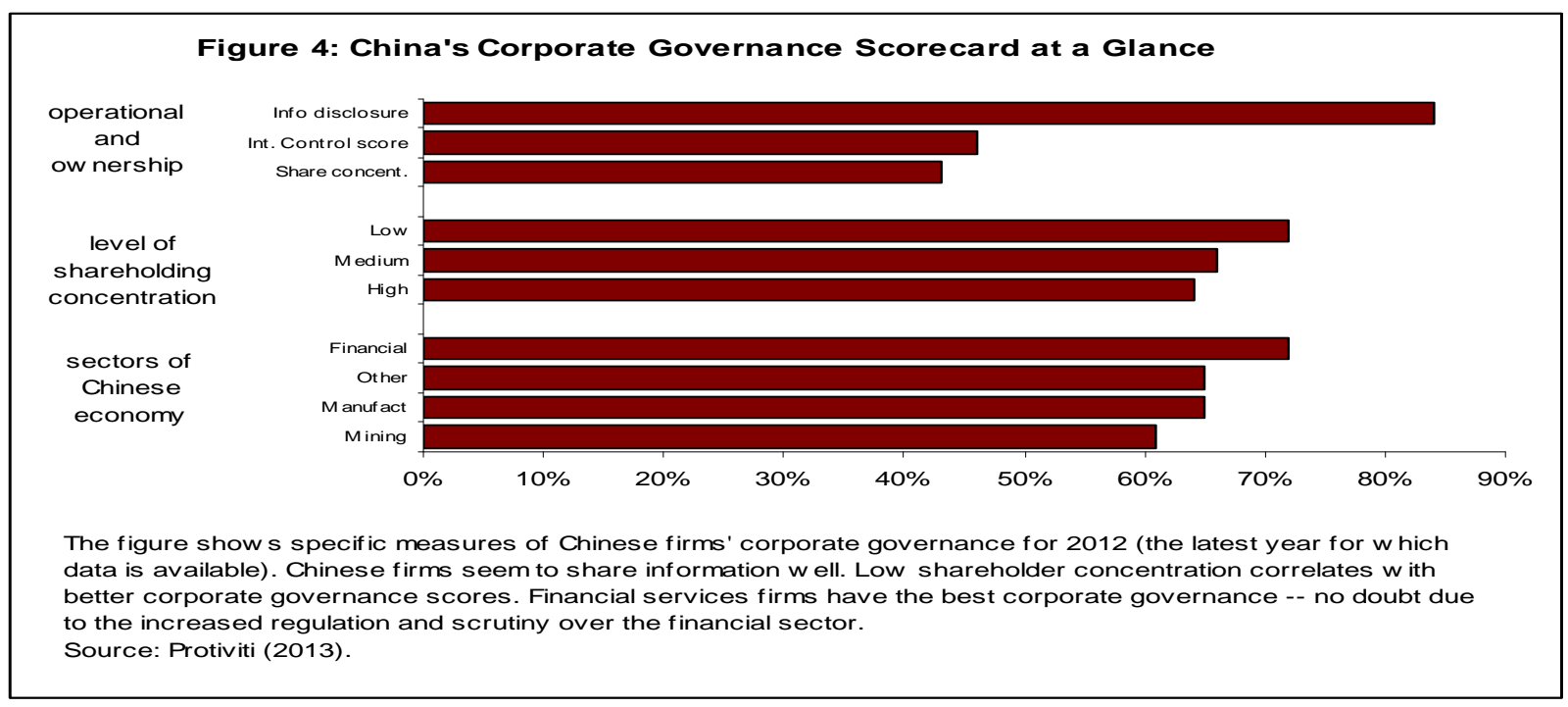

Even a rudimentary glance at various Chinese companies' corporate practices show reasons for these firms' low corporate governance scores. Figure 4 (already shown above) shows three summary statistics about governance practices among Chinese companies - the extent of information disclosure, the extent of internal control and the extent of concentration among shareholders. While information disclosure ranks highly, lower internal control scores combined with very concentrated shareholdings -- point to the large role that concentrated shareholders (rather than rules and regulations) play in governing Chinese business. Companies with high shareholder concentration have corporate governance scores of around $60 \%$. Companies with low shareholding concentration have corporate governance scores of around $75 \%$. The effects of corporate governance policies, like shareholder concentration or not, matter far less than the effects of such concentration - something that specific corporate governance regulations can manage (whether hard or soft). ${ }^{25}$

\footnotetext{
${ }^{24}$ Galander and co-authors similarly find that Germany's soft law financial regulations performed well, not because they entered into hard law, but because the rules' specificity, concreteness, and use to form and force expectations. See Galander, Anne, Peter Walgenbach and Katja Rost, Corporate Governance Soft Law Regulations from a Social Norm Perspective, Corporate Governance 15(1), 2015, available online.

${ }^{25}$ This pithy sentence reads blithely, yet accurately. In a system designed to give primacy to personal relationships, regulations should clearly guide the personalities involved in making corporate governance "understandings" and settling disputes. For a description of the personalized nature of corporate governance in China, see Yang, Jing-Jing, Jing Chi, and Martin Young, A Review of Corporate Governance in China, Asian-Pacific Economic Literature 25, 2011, available online.
} 
A look at disclosure rules and their effects best illustrates the need to focus on regulations managing the effects of corporate governance rules. ${ }^{26}$ Figure 5 shows the improvement in various attributes of disclosure and corporate governance in Chinese (Mainland and Hong Kong) companies. ${ }^{27}$ On a five point scale, increases in corporate information barely score 2 out of 5. Disclosure comprehensiveness scores a bit less than 1, at a time when the Mainland's code of corporate governance had already been in force for five years. Yet, even with the most progressive rules (as illustrated by UK and German companies), companies do not voluntarily disclose more (or more relevant) information. Figure 6 shows the extent to which listed firms in the UK and Germany (as relatively progressive markets) comply with their corporate governance rules. $^{28}$ Only around $70 \%$ of the very largest UK listed firms complied with that country's corporate governance rules. Many fewer of Germany’s largest listed companies complied with their version of corporate governance rules. Taken together these data show that simply "improving" corporate governance rules will likely have little effect on Mainland information disclosure. Rules develop “around” corporate governance rules - such as 'bonding' rules -- to provide remedies for both hard and soft rules which depend on the personalities affected by those rules. $^{29}$

\footnotetext{
${ }^{26}$ We do not have space to review these disclosure requirements. Readers interested in an in-depth discussion should see Fu, Jane, Corporate Disclosure and Corporate Governance in China, 2010.

${ }^{27}$ See CFA Institute, China Corporate Governance Survey, 2007, available online.

${ }^{28}$ See Seidl, David, Paul Sanderson, and John Roberts, Applying ‘Comply-Or-Explain’: Conformance With Codes of Corporate Governance in the UK and Germany, University of Cambridge Centre for Business Research Working Paper No. 389, 2009, available online.

${ }^{29}$ Bonding refers to expectations minority shareholders have to rights when formal rules give them few, vis-a-vis block or majority shareholders. See Cai, Hua, Bonding, Law Enforcement and Corporate Governance in China, Stanford Journal of the Law of Business and Finance 13, 2008. As if to belabour the point about the personalisation of corporate governance law, see Shi, Chen-xia, Political Determinants of Corporate Governance in China, Routledge, 2012.
} 

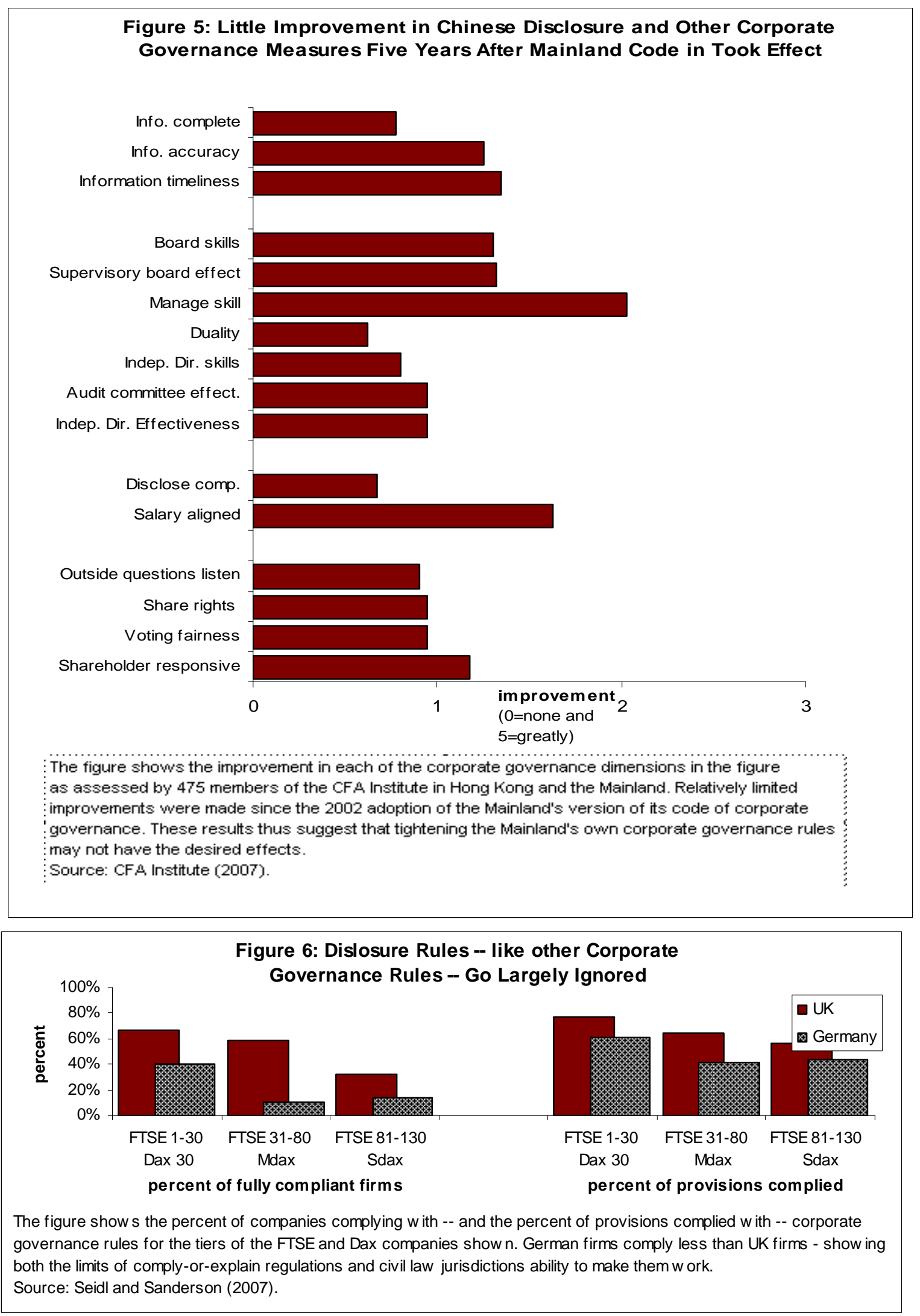
A few examples of the personalisation of corporate governance in China make plain that hard rules serve to promote concrete expectations and aim in coordination more than as a mechanism for transferring rights, obligations and the basis for private/enforcement (as in the private agency view of corporate governance). ${ }^{30}$ First, Chow notes more disclosure and better governance could actually cost managers their lives and freedom. ${ }^{31}$ The Communist Party uses politically motivated purges of companies and government bodies using the information obtainable from more open corporate reporting (as support for anticorruption investigations and prosecutions). In such an environment, no company has the incentive to freely disclose information. The government uses such opacity to conceal the real reasons for politically motivated prosecutions. Second, as Narine notes, disclosures rely on the company's stakeholders to act on these disclosures. ${ }^{32}$ The recent Sanlu case (of tainted milk) best illustrates how discretionary government involvement in corporate affairs on the Mainland make disclosure rules impossible to adopt and enforce. ${ }^{33}$ In that case, the government actively discouraged corporate executives from making disclosures that could have saved lives and investors money. ${ }^{34}$ With stakeholders unable or unwilling to act on information (due to government policy), the value within the country of such information remains questionable. Even wide-spread fraud among Mainland firms listed abroad has not led to any kind of domestic response on the Mainland - either for tighter rules as promulgated by the government or criticism from investors and other stakeholders. ${ }^{35}$ Indeed, disclosure remains at such a basic level as to hinder even researchers looking the extent of disclosure among Chinese firms. ${ }^{36}$ In these contexts, personality mattered more than hard or soft law - reform of corporate governance law should take such personality into account.

\section{Increasing Participation as the Driver of Corporate Governance Regulatory Change}

The management of China's state-owned enterprises best illustrates the problems of writing and trying to use corporate governance hard and soft law. $\mathrm{Xu}$ and $\mathrm{Xu}$ describe the travails of China's Open State Owned Enterprise (SOE) Information Bill. ${ }^{37}$ They argue that the public has an even larger right to information about SOEs, as the government and these SOEs work in the interests of the people. ${ }^{38}$ Their argument about access to information as a human right, as a way to lower

\footnotetext{
${ }^{30}$ That is not to say that nothing in Chinese corporation relations supports the Western style agency theory as a rationale for regulation. See Canan Mutlu, Marc Van Essen, Mike Peng, Sabrina Saleh, Agency Theory and Corporate Governance in China: A Meta-Analysis, Bepress Working Paper, 2016, avialable online.

${ }^{31}$ Chow, Daniel, How China's Crackdown on Corruption Has Led to Less Transparency in the Enforcement of China's Anti-Bribery Laws, U.C. Davis Law Review 49(2), 2015, available online.

${ }^{32}$ Narine talks about the effects of disclosure on human rights. Yet, her discussion is entirely general. See Narine, Marcia, Disclosing Disclosure's Defects: Addressing Corporate Irresponsibility for Human Rights Impacts, Columbia Human Rights Law Review 47(1), 2015.

${ }^{33}$ See Fu, Jenny and Geoffrey Nicoll, The Milk Scandal and Corporate Governance in China, Canberra Law Review 10(3), 2011.

${ }^{34}$ Id at p. 123.

${ }^{35}$ See McCarty, Janelle, Mergers \& Accusations: Chinese Auditing and Corporate Disclosure Standards Indirectly on Trial in the United States, Minnesota Journal of International Law 21(2), 2012.

${ }^{36}$ See Tucker, Jennifer and Xin-Min Zhang, Corporate disclosure and research opportunities in China, Journal of Accounting Studies, 2016, available online.

${ }^{37}$ We could not find any mention of the adoption of the proposed Act. We thus must rely on Xu and Xu's description. See Xu, Xue-Lei Xu and Xin Xu, Information Disclosure of State-Owned Enterprises in China, Tsinghua China Law Review 4(1), 2011, available online.

${ }^{38}$ Id at p. 4.
} 
social costs, and to reduce conflicts of interest in government might seem strange to western ears. ${ }^{39}$ Yet, when considered in the light of our thesis, their call for greater transparency echoes the need for shared understandings for coordination. The authors note only information sharing which harms the corporation and its interests should remain undisclosed - as "the bottom line should be defined: once information is disclosed to the public, the corporation will suffer substantial losses. For example, the proprietary knowledge of a corporation should not be disclosed because leaks in proprietary knowledge will provide the corporation's competitors with an obvious advantage." 40 Such a legal doctrine seems at odds with past SOE management in China. ${ }^{41}$ Nevertheless, as a contributor to the OECD guidelines on the corporate governance of SOEs, the government "Recognis[es] that state-owned enterprises face some distinct governance challenges arising from the fact that their ownership is exercised by government officials on behalf of the general public." 42 As the public becomes a larger and more important stakeholder in China's corporations (state owned and not), corporate governance law needs to accommodate their participation in China's corporate life. ${ }^{43}$

The data further show that the Mainland's SOEs need special rules and enforcement practices in order just to catch up with private sector firms. Figure 7 shows the percent of Chinese SOEs providing information about various aspects of their corporate existence and operations. ${ }^{44}$ Most state-owned enterprises disclose information about their organisational structure (though the extent to which they report on the exact structure...including relations with offshore entities...remains unknown). ${ }^{45}$ Reports about capital investment remain popular - as a way SOE executives can brag to the central government. ${ }^{46}$ If heavy industry continues to release news about its achievements, service, agricultural and even information technology companies have far less political and economic clout, as reflected in their lacklustre reporting. Only $9 \%$ of companies provide information about their human resources. Such a situation doesn't - as most commentators suggest - show the backwardness or lack modernity in China's corporate

\footnotetext{
${ }^{39}$ Id. III.D.

${ }^{40}$ Id at p. 32.

${ }^{41}$ Zhang, Dong and Owen Freestone, China's Unfinished State-Owned Enterprise Reforms, Australian Treasury Economic Roundup 2, 2013, available online.

42 OECD, OECD Guidelines on Corporate Governance of State-Owned Enterprises, 2015, at p. 9 (Recommendation of the Council on Guidelines on Corporate Governance of State-Owned Enterprises), available online.

${ }^{43}$ Wang best illustrates this shifting need - from Party members to the wider public - for corporate governance rules which facilitate and coordinate action. Tenev and co-authors provide a less philosophical, and more tangible, description of such increasing participation. See Wang, Zhao-Feng, Corporate Governance Under State Control: The Chinese Experience, Theoretical Inquiries in Law 13.2, 2012, available online. See also Tenev, Stoyan, Chun-lin Zhang, and Loup Brefort, Corporate Governance and Enterprise Reform in China: Building the Institutions of Modern Markets. World Bank Monograph, 2002, available online.

${ }^{44}$ See See Xu, Xue-Lei Xu and Xin Xu, Information Disclosure of State-Owned Enterprises in China, Tsinghua China Law Review 4(1), 2011, at p. 23, available online

${ }^{45}$ China's Going Out Policy further complicates matters - as these firms may have legitimate commercial interests offshore which represent more than simply incorporating shell companies in offshore fiscal paradises. See Chen, Duan-Jie, China’s State-Owned Enterprises: How Much Do We Know? From CNOOC to its Siblings? University of Calgary School of Public Policy Research Paper 6(19), 2013, available online.

46 The politics of investment often over-ride the economics of profit maximisation, making corporate governance far less necessary for these SOEs without a clear policy from the centre. See Leutert, Wendy, Challenges Ahead in China's Reform of State-Owned Enterprises, Asia Policy 21, 2016, available online.
} 
governance. ${ }^{47}$ The choice between using hard versus soft law isn't the same as choosing to drive in over-drive versus cruise. ${ }^{48}$ Lack of principles and purposes of transparency and disclosure for these SOEs make working with these companies unpredictable for all parties under conditions when higher ranking Party officials do not always define the governance regime they want dynamically and win every argument. ${ }^{49}$ "Integrated fragmentation” may represent the way the Party and business interact - but such an arrangement does not help with the governance of China's SOEs, private companies, nor set the basis for conflict and coordination inherent in any corporate governance rules. $^{50}$

\footnotetext{
${ }^{47}$ For such a modernist view, see Howson, Nicholas and Vikramaditya Khanna, The Development of Modern Corporate Governance in China and India, In M. Sornarajah and J. Wang, China, India and the International Economic Order, Cambridge University Press, 2010.

${ }^{48}$ The view of good corporate governance, as a destination which governments can use laws to arrive at more or less quickly, permeates the literature. See Miles, Lilian \& Zhong Zhang, Improving Corporate Governance in StateOwned Corporations in China: Which Way Forward?, Journal of Corporate Law Studies 6(1), 2006. See also Wang, Jiang-Yu, Corporate Governance in China: The Law and Its Political Logic, In Roman Tomasic Ed., Routledge Handbook of Corporate Law, Routledge, 2016) at Chapter 11.

${ }^{49}$ Baosteel represents a fascinating case study into the informal norms and politics that defines China's corporate governance of state-owned enterprises. To summarise the author's point, "The People’s Standing Committee, the highest Chinese Communist Party organization of China's state owned enterprises [serves a] complementary role for an imperfect board of directors in corporations which [follow the] modern enterprise system, and provides supervision and assistance [ ] to corporate top management as an internal control mechanism" (we edited as shown to clarify the English). See Cho, Dong-Sung and Fei Huang, A Study on Corporate Governance of China's State-Owned Enterprises -- Focus on the Role of the Baosteel CCP's Organization. Journal of International Business Research 10(1), 2011, available online.

${ }^{50}$ Brodsgaard, Kjeld, Politics and Business Group Formation in China: The Party in Control? China Quarterly 211(1), 2012.
} 


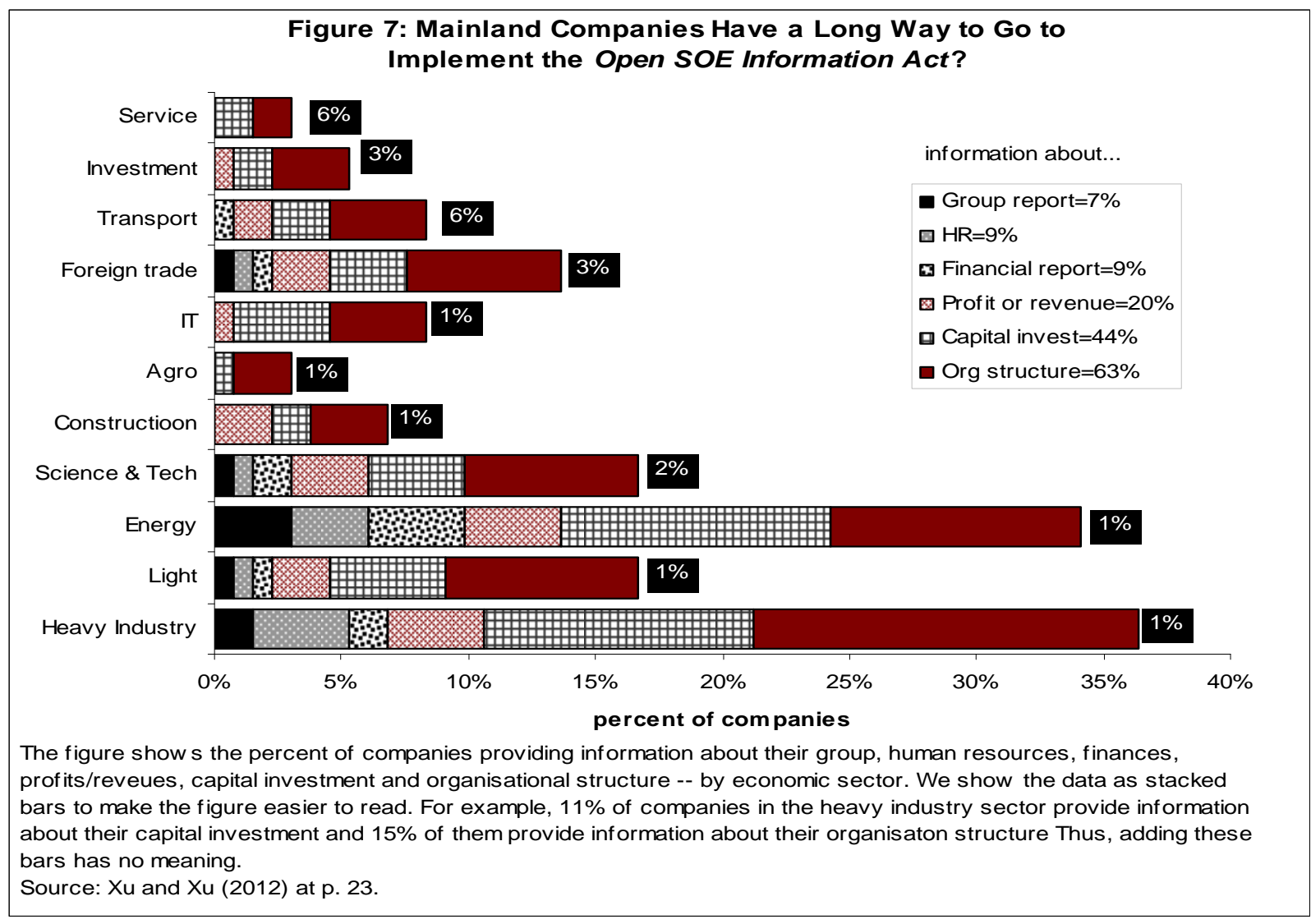

Nothing shows the misunderstandings arising from China's corporate governance soft law than the frauds discovered in Chinese corporations listed abroad through a manoeuvre knows as a "backdoor listing" 51 A backdoor listing occurs when a company unable or unwilling to engage in an initial public offering cooperates with already listed company to buy the unlisted company. Figure 8 shows the number of reverse mergers (or backdoor listings) by Mainland companies in the US and UK. ${ }^{52}$ Despite the global financial crisis, these de facto IPOs have increased over time. Regulation clearly plays a role - as Chinese companies overwhelmingly chose the US, rather than the UK, to list. ${ }^{53}$ Yet, we know that $75 \%$ of finance professionals polled in a recent survey answered 'no' to the question about whether the current backdoor listing rules are effective. $^{54}$ The flurry of delistings of backdoor listed Chinese companies in the US, due to fraud or other problems - seems to suggest that these listings correspond with poor corporate governance in the firms concerned. Figure 9 shows the number of these backdoor listings eventually delisted by year. ${ }^{55}$ On average, corporate malfeasance and the consequent delisting

\footnotetext{
${ }^{51}$ Readers unfamiliar with backdoor listings (reverse mergers) should see Erik Vermeulen, Rules on Backdoor Listings: A Global Survey, 2014, available online. See also Jan Jindra, Torben Voetmann, and Ralph A. Walkling, Reverse Mergers: The Chinese Experience, Fischer College of Business Working Paper 2012-03-018, 2012, available online.

${ }^{52}$ See Cornerstone Research: Investigations and Litigation Related to Chinese Reverse Merger Companies: Financial, Economic, and Accounting Questions, 2011, available online.

${ }^{53}$ We do not know the trends for Hong Kong because the SFC has been either unable or unwilling to collect and publish these statistics.

54 SFC, SFC Regulatory Forum 2016, Polling Results, 2016, available online.

55 See Charles Lee, Kevin Li, and Ran Zhang, Shell Games: The Long Term Performance of Chinese Reverse Merger Firms, 2014, available online.
} 
took about 6 years. Figure 10 shows the Bloomberg Chinese reverse merger index and the number of class action lawsuits against these Mainland corporations. As shown, the reverse merger index fell as fraud cases piled up - showing how lax corporate governance can harm company valuations. Yet, one (Western) person's fraud represents another (Chinese) person's misunderstanding. ${ }^{56}$
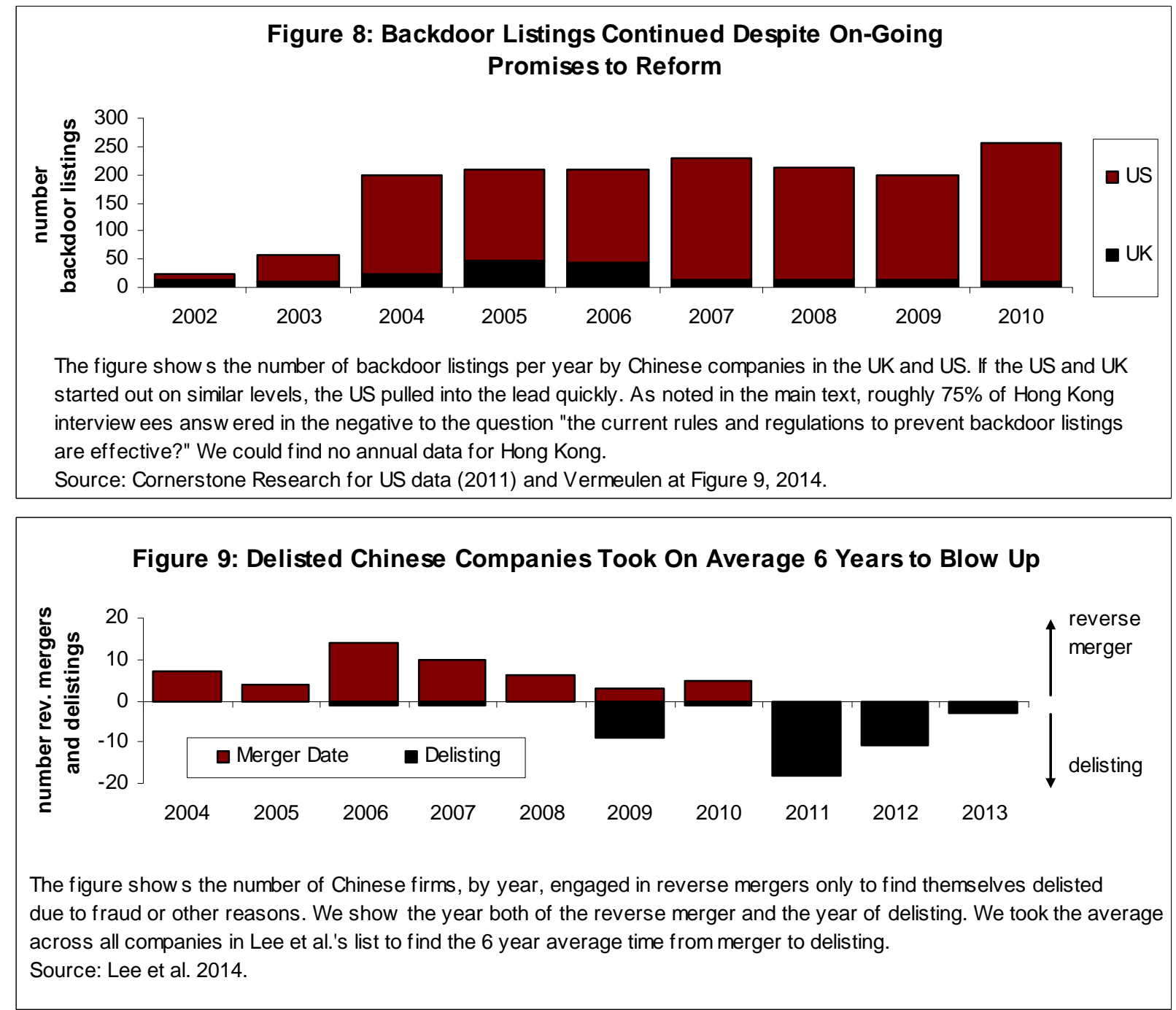

\footnotetext{
${ }^{56}$ Such a "misunderstanding" would not represent a misunderstanding in China, where expectations allow for, and expect, such business practices... understood by all parties. For a misunderstand of this misunderstanding, see Shan, Yuan and David Round, China's Corporate Governance: Emerging Issues and Problems, Modern Asian Studies 46(5), 2012.
} 


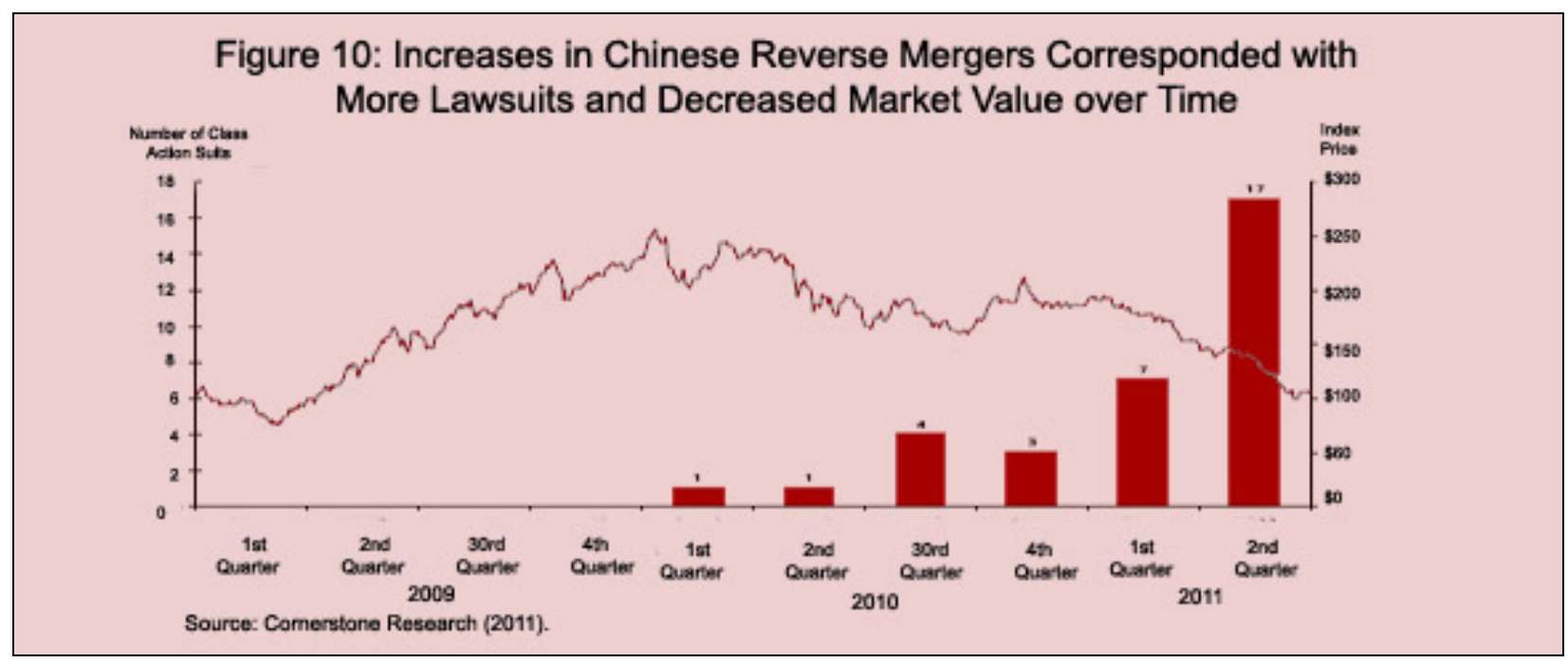

Many observers blame reverse mergers themselves for the reduction of the quality of listed companies. Yet, as Chen and colleagues note, a "China effect” explains these listings' problems much better than any "reverse merger effect." M7 Mainland companies' managers and even Communist Party overseers clearly failed to detect and rectify significant weaknesses in these companies' accounting and corporate governance standards - leading to valuations which only came to half those of their IPO counterparts. ${ }^{58}$ Such events belie these overseers' "complementary role for an imperfect board of directors in corporations which [follow the] modern enterprise system, and provides supervision and assistance [ ] to corporate top management as an internal control mechanism." 59 The current regime of "fragmented authoritarianism" shows that China's hard corporate governance isn’t hard enough, and soft corporate governance is not soft enough. ${ }^{60}$ “'Fragmented authoritarianism' [is] where a central government agency has instituted pre-enforcement designs that systematically constrain the economic and directorial power of the PRC's most powerful, formally non-governmental,

\footnotetext{
${ }^{57}$ See Chen, Kun-Chih, Cheng Qiang, Ying-Chou Lin, Yu-Chen Lin and Xiao Xing, Financial Reporting Quality of Chinese Reverse Merger Firms: The Reverse Merger Effect or the China Effect?", Singapore Management University's School of Accountancy Working Paper 12-2013, 2013, available online.

${ }^{58}$ Initial public offerings (IPOs) result in the listing of companies following higher standards due the significant screening done before listing. In contrast, screening of companies listing via reverse mergers remains lax in the US, Hong Kong and other jurisdictions. Yet, not everyone agrees about these harms. Chai et al. dispute that reverse merger firms perform worse than IPOs or Chinese companies based in the US. Chai and Lau see nothing sinister about the delisting we have shown - as companies with poor corporate governance got kicked out, and those staying adopted even higher corporate governance standards. See also Chai, Mary and Virginia Lau, Bonding versus Avoiding Theory: Evidence from Accrual and Real Earnings Management of Chinese Reverse Merger Companies, AFAANZ 2016 Conference, available online. For the market value statistics we cite, see PCAOB, Activity Summary and Audit Implications for Reverse Mergers Involving Companies from the China Region: 2 January 1, 2007 through March 31, 2010, PCAOB Research Note 2011-P1, available online. See also Chai, Mary Virginia Lau, Kitty Xie, The End Justifies the Means? Signalling Effect of How and Where to List, Paper\#: K227, Seventh Asia Pacific Interdisciplinary Research in Accounting Conference, Kobe 26-28 July, 2013, available online.

${ }^{59}$ We took Cho and Huang's quote from previously, and introduced it in the main text. We repeat the quote to underline the importance this world-view has on Chinese corporate governance.

${ }^{60}$ Nicholas Howson, 'Quack Corporate Governance' as Traditional Chinese Medicine - The Securities Regulation Cannibalization of China's Corporate Law and a State Regulator's Battle Against Party State Political Economic Power, Seattle University Law Review 37, 2014, available online.
} 
political economic actors.” ${ }^{61}$ Clearly, China’s corporate governance exhibits integrated fragmentation and fragmented authoritarianism - a condition whereby China's elites try to help manage China's corporations, while these elites try to keep corporate governance laws fuzzy enough to stop the central authorities from disrupting their understandings with company managers. Conventional commentators which miss this dialectic miss the whole dynamic rendering the distinction between China's hard and soft corporate governance law moot. ${ }^{62}$ Rules should be "coordinatable."

\section{Updating China's Code of Corporate Governance and Other Regulations}

Many studies we have already reviewed have argued that Chinese corporate governance would improve only if China's rules improved. Foreign listings of Chinese companies supposedly import foreign corporate governance rules. ${ }^{63}$ Many of these companies incorporate offshore making offshore incorporations a key part of this import process. ${ }^{64}$ We previously dispelled the notion that Chinese companies can import "better" corporate governance rules. Yet, no one can deny that some corporate governance rules help improve companies' market valuations more than others. Figure 11, for example, shows the way that Chinese market valuations have changed in response to the valuation of their American Depository Receipts (ADRs). ${ }^{65}$ Offering access to Chinese companies' shares in the US has significantly more effects on Mainland companies’ market values than offering such access in Hong Kong or Taiwan.

\footnotetext{
${ }^{61}$ Id at p. 1.

${ }^{62}$ Literally hundreds of modernist writers treat Chinese corporate governance like a game or skill which Chinese have learnt poorly compared to other jurisdictions. See On Kit Tam, On Kit and Celina Ping Yu, China’s Corporate Governance Development, In Christine A. Mallin, Christine, Handbook on International Corporate Governance, 2011. See also Guo, Liang, Clive Smallman, and Jack Radford. A critique of corporate governance in China, International Journal of Law and Management 55(4), 2013, available online. We could go on all day.

63 To take an example, Sun and Tobin argue that Bank of China's cross-listing in Hong Kong helped promote convergence of its corporate governance. Yet, they provide no evidence - listing data on financial performance instead. See Sun, Lai-Xiang and Damian Tobin, Corporate Governance Reform and International Listing: Case of the Bank of China (Hong Kong), Centre for Financial and Management Studies Discussion Paper, 2003, available online.

${ }^{64}$ The British Virgin Islands in the Bank of China case cited in the main body of this paper. See Id at Figure 1.

${ }^{65}$ Pan, Lee-Hsien, Chien-Ting Lin , and K.C. Chen, ADR Characteristics and Corporate Governance in the Greater China Region, Review of Development Finance 2, 2012, available online.
} 


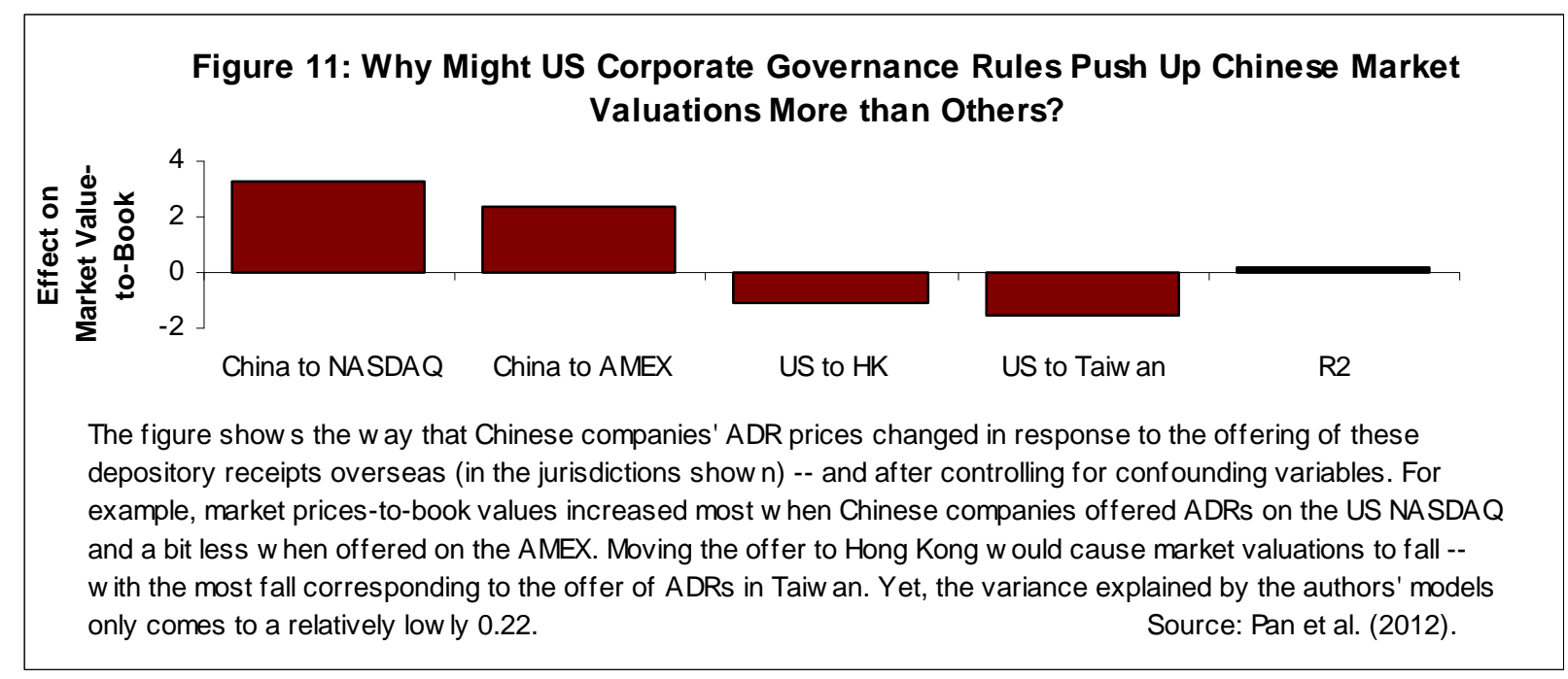

How have Mainland corporate governance rules adapted to changing markets and growing access to foreign exchanges? China's corporate governance regulations - as well as corporate governance itself - have changed (improved from a Western mindset) by leaps and bounds since the 2002 publication of its Code of Corporate Governance. ${ }^{66}$ Yet, by senior officials' own admission, China's corporate governance regulations should improve far more in a wide-array of ways. Figure 12 shows the most important areas recently identified by senior Chinese officials themselves. ${ }^{67}$ Disseminating a revised code of corporate governance probably represents the easiest task to accomplish. Yet, even scratching at the surface of the most important recommendations reveals a completely different notion of what Chinese commentators actually mean. "Removing soft budget constraints in former state owned enterprises," for example, does not mean their complete elimination (as senior Party members can easy ban such lending). Such reform requires that "to harden budget constraints, political institutions need to be reconfigured to allow the central government more effectively to hold local authorities accountable for resources deployed in achieving their job-performance targets."68 Something very different - basically asserting that oversight should stop stupid (unprofitable) lending. The rules governing such lending should coordinatable - allowing soft lending in a way which allows managers to achieve goals, rather than personal interests. ${ }^{69}$

\footnotetext{
${ }^{66}$ See China Securities Regulatory Commission, Code of Corporate Governance for Listed Companies in China, Zhengjianfa No.1 of 2002, 2002, available online.

${ }^{67}$ For example, see Hu, Ru-Yin, Efforts to Improve Corporate Governance in China, OECD Conference on the Corporate Governance of State Owned Enterprises, 2015, available online. See also Protiviti (2013) at Tables 2 and 3.

${ }^{68}$ Indeed, the current system could hardly survive with such soft-lending. Ong provides the quote, while Skoog shows why Mainland officials would never even conceive of "removing” as 'ending' soft lending - but rather as ending unproductive soft lending arising from coordination problems. See Ong, Lynette, Fiscal federalism and soft budget constraints: The case of China, International Political Science Review 33(4), 2011, at p. 455. See also Skoog, Gun-Eriksson, The Soft Budget Constraint - The Emergence, Persistence and Logic of an Institution, Springer, 2000.

${ }^{69} \mathrm{Wu}$ shows this most clearly; he hardly needs to draw on decades of failure to reform soft budget constraints as evidence of the need to coordinate governance reform in a way which benefits all parties. See Wu, Alfred, Searching for Fiscal Responsibility: A Critical Review of the Budget Reform in China, China: An International Journal 12 (1), 2014, available online.
} 


\section{Figure 12: Introducing a Consolidated Code of Corporate Governance Probably Easiest Out Of All Chinese Self-Admitted Corporate Governance Defects}

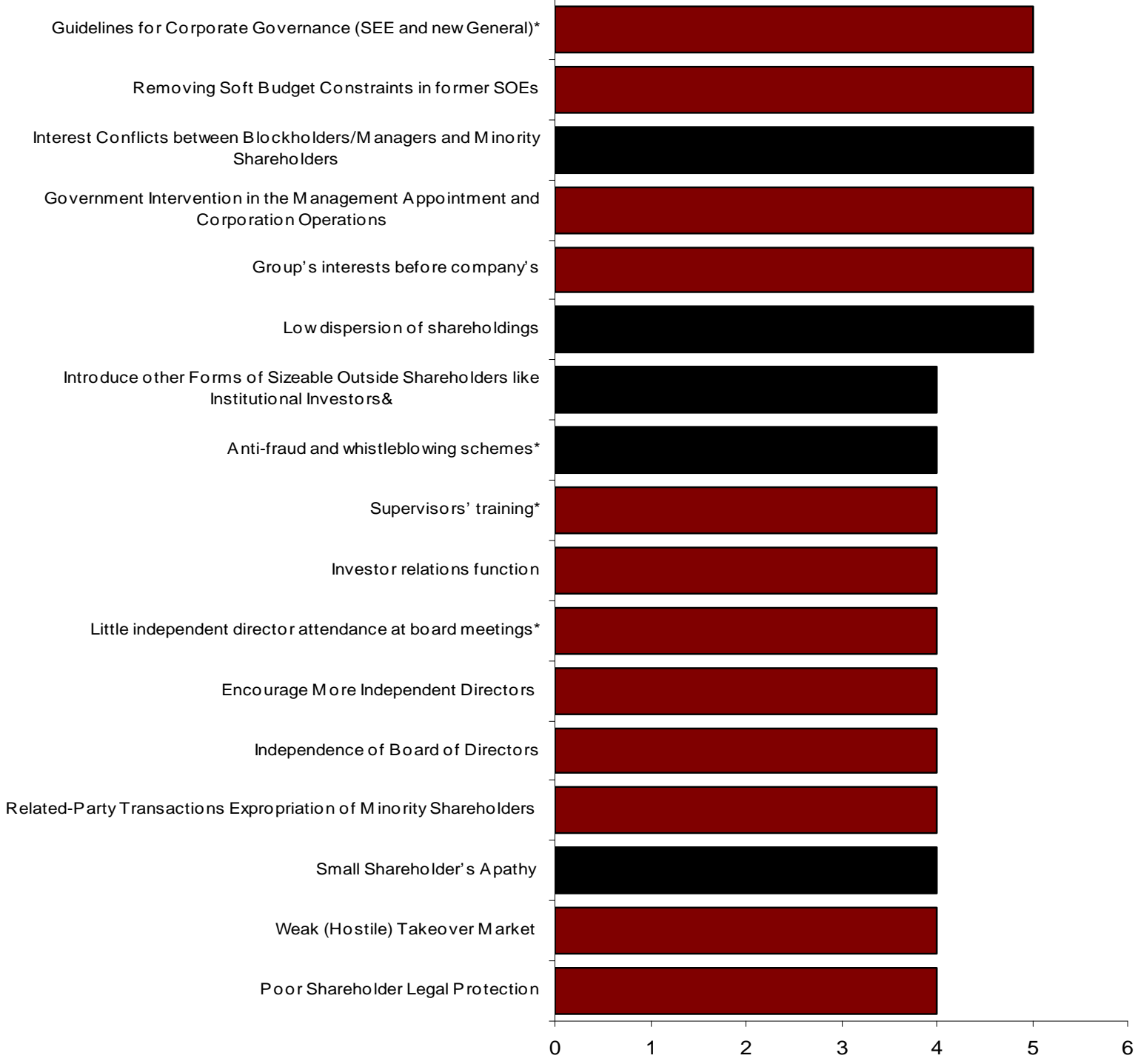

The figure shows the activities identified by Chinese officials to improve the Mainland's corporate governance. Hong Kong has already developed significant experience in tackling most of these issues.

* represents an easy activity (1-3)

black bars represent an activity which Hong Kong has yet to master itself.

Basic drafting problems - namely the scattering of corporate governance provisions across legislative or administrative instruments -- hinders Chinese directors and corporate stakeholders from understanding corporate governance obligations and best practices. The legislative acts containing corporate governance provisions include the 2006 Company Law (mainly about shareholder protection and board structure), the 2006 Securities Law (mainly governing investor 
protection and disclosure), the 2006 Criminal Law Amendment Act (mainly fraud, insider trading and non-compliance with other regulations), the 2009 Law on the State-Owned Assets of Enterprises (regulating mainly how state owned enterprises should behave), and the 2000 Accounting Law (ensuring accurate financial reporting and oversight). ${ }^{70}$ Other peripheral rules include the 2007 Regulations on Listed Companies’ Information Disclosure, the 2006 Guidance on Listed Companies' Articles of Association, the 2006 Rules on Listed Companies’ Shareholders' Meetings, the 2001 Guiding Opinions on the Establishment of the System of Independent Directors in Listed Companies, the 2004 Provisions on Strengthening the Protection of the Rights and Interests of Public Shareholders, the 2006 Regulations on the Takeover of Listed Companies, the 2008 Regulations on Major Asset Reorganisation of Listed Companies, the 2005 Regulations on Equity Incentives of Listed Companies, the 2006 Regulations on the Registration and Settlement of Securities and the 2008 Basic Standard for Enterprise Internal Control. ${ }^{71}$ We could not find the rules governing Articles of Association of Companies Seeking a Listing outside the PRC Prerequisite Clauses at all. We do not discuss specific corporate governance rules focused on securities/financial firms. ${ }^{72}$

What is the extent of such scattering? As shown in Figure 13, companies need to consult at least 7 laws in order to assess the extent to which they comply with the OECD Corporate Governance Principles. As shown, the Company Law contains most of the relevant provisions. Yet, the official code of corporate governance applies to only about $15 \%$ of the relevant provisions. Such dispersion complicates managers' ability to draft relevant corporate governance decisions and internal auditors' ability to check them. Obviously problems must exist - given the poor governance performance of the Mainland's companies. As noted previously, on a 5 point scale of improvement, none of the areas of corporate governance tracked improved by 3 points or more. ${ }^{73}$

\footnotetext{
${ }^{70}$ We take these laws from Yang and co-authors. See Yang, Hua, Zehua Ouyang, Li-Xin Zhao, Jian-Chun Cai, Qian-Song An, Bo-Jin Yan, Yan Liu, Ming Huang, Wei-Dong Zhang, Chun-Sheng Pan, Huan Zhu, Li Gao, XingHui Jiang, Hong-Xia Sun, Xue-Yue Jiang, Zhao-Hui Chen, Jian-Shan Huang, Xu Yong, Shun-Ying Ren, Jiang-Xuan She, Wei Ren, and Hong-Da Zhou, Corporate Governance of Listed Companies in China: Self-Assessment by the China Securities Regulatory Commission, 2011, available online.

${ }^{71}$ We do not link to all of these - as they are mostly peripheral to our discussion. For readers interested in these rules, and the institutional system generating them, see Shi, Chen-Xia, Political Determinants of Corporate Governance in China, 2012.

${ }^{72}$ See CSRC, Provisional Code of Corporate Governance for Securities Companies, 2004, available online.

${ }^{73}$ CFA Institute, China Corporate Governance Survey, 2007, available online.
} 


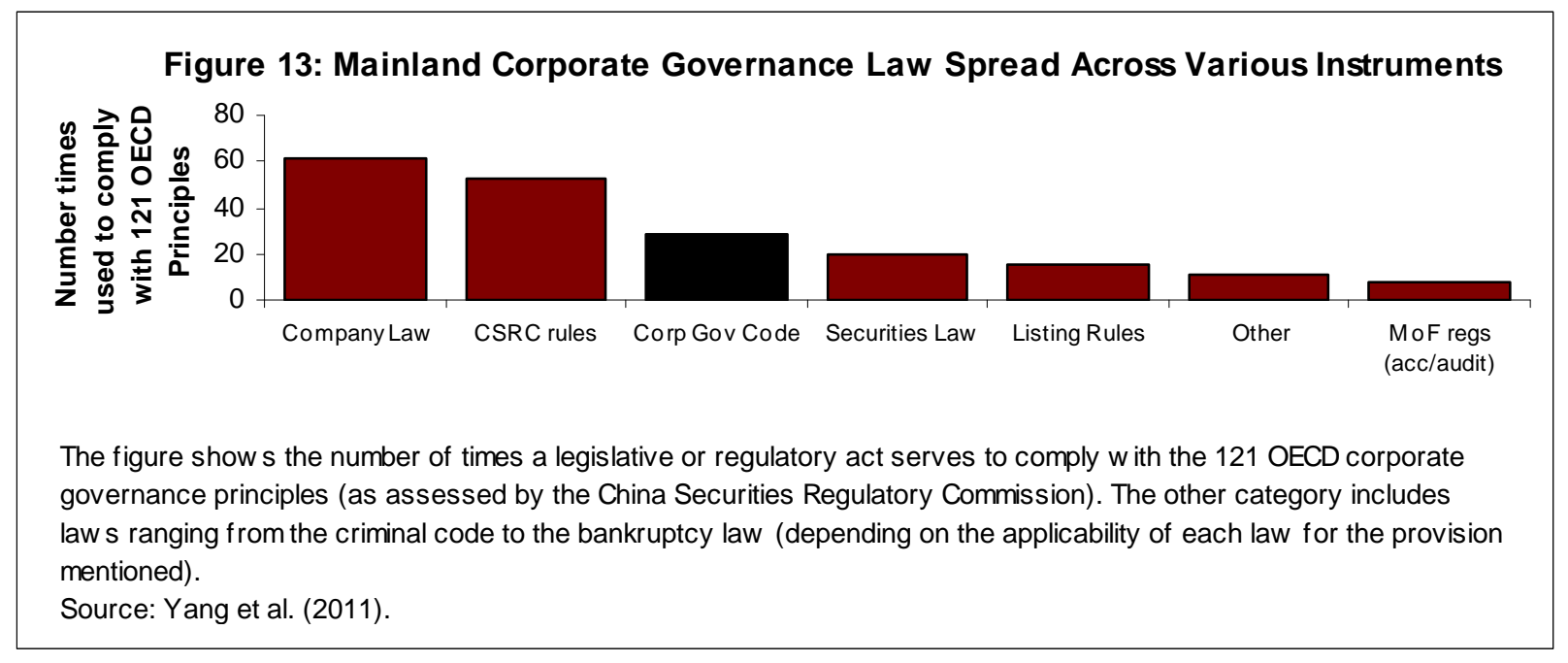

How can Chinese stakeholders coordinate using corporate governance rules which define principles too vague to understand, much less adopt and rely upon? Figure 14 shows the principles enshrined in the Chinese Code of Corporate Governance. ${ }^{74}$ Defining some terms like "damage”, "necessary means" or interference” remain uncontroversial - and indeed similar in Hong Kong's code. Yet, three principles in particular look very difficult to interpret in a Mainland context. First, particularly Section 2 of Chapter 2's the Independence of Listed Company stipulates that, "controlling shareholders shall respect the financial independence of the company and shall not interfere."75 The obvious question arises about the extent to which government officials and state-owned entities serving as controlling shareholders can (or should) refrain from directing and interfering in these companies. We have already pointed to the social mandate given to China's companies - both state-owned and private. Second, Chapter 7(3) covers the declaration of beneficial ownership in Mainland companies. The section requires the declaration to shareholders of persons who a) own a comparatively large percentage of shares of the company, b) actually control the company when acting in concert, c) change their shareholding (and/or factors causing such changes), d) pledge the company's shares, and/or e) transfer control of the company. ${ }^{76}$

\footnotetext{
${ }^{74}$ China Securities Regulatory Commission, Code of Corporate Governance for Listed Companies in China, Zheng Jian Fa No.1 of 2002, 2002, available online.

${ }^{75}$ Several articles in the section contain this formulaic phrase.

76 The declaration to shareholder probably constitutes a minimum standard. When viewed in combination with Chapter 6 and 7.1, one could claim that such information sharing can extend beyond shareholders to the wider community of the firms' stakeholders.
} 


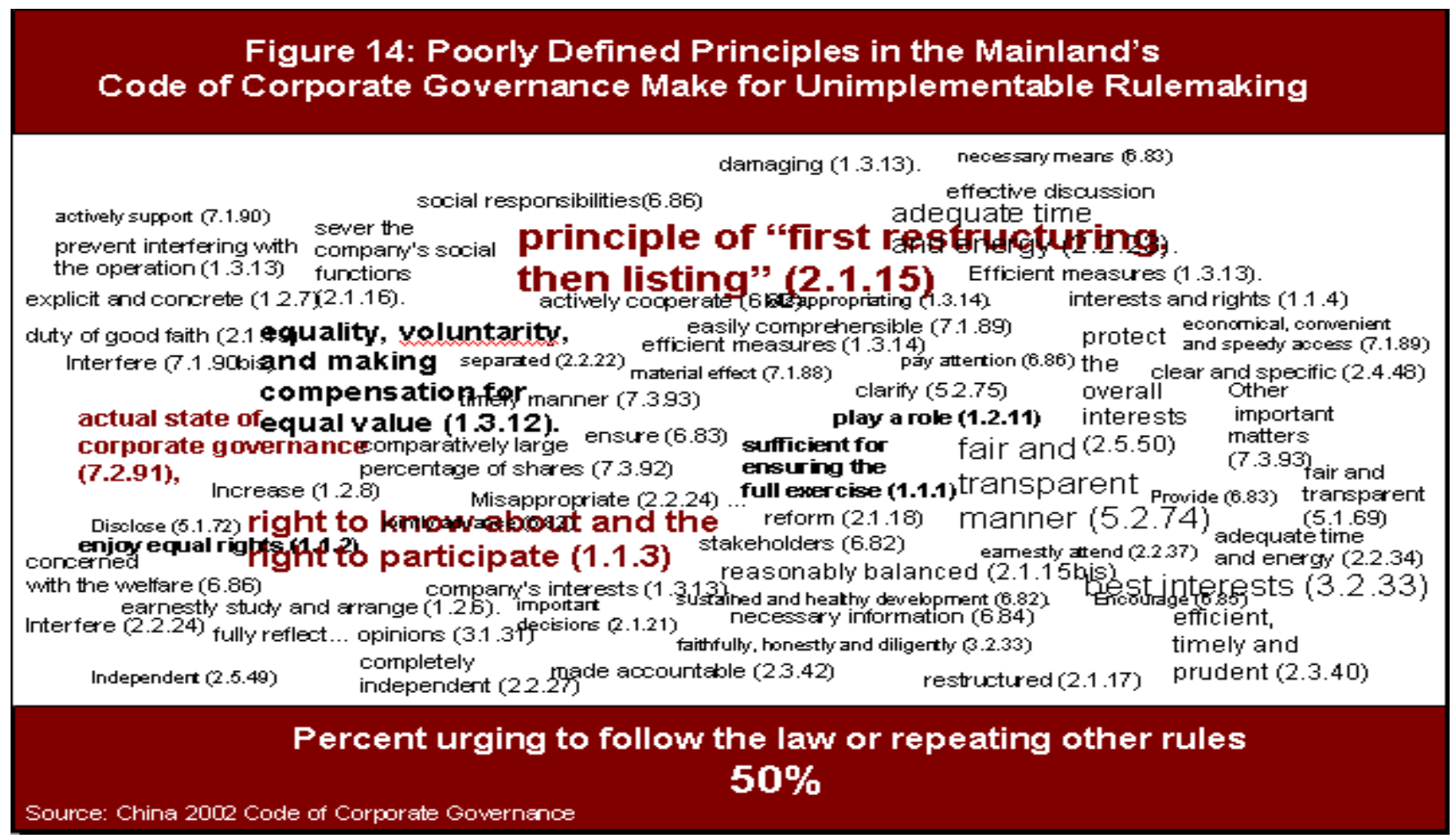

Tightening principles based on their coordinatability would allow for corporate governance codes which reduce, rather than increase, uncertain abstraction in China's law. Chapter 6 of the Code looks suspiciously like the socialist regulation which the government has supposedly tried to rollback for decades. Article 86 admonishes companies to consider the "welfare, environmental protection and public interests of the community in which it resides, and ... pay attention to the company's social responsibilities."77 Proposals abound for making this text more concrete. ${ }^{78}$ Most revolve around concrete and specific rules, placed into the classical branches of law as a Western scholar might see these branches (labour, criminal, civil, etc.). ${ }^{79}$ Hard or soft reforms in areas targeted by Article 86 have failed, not because they comprised hard or soft law, but because these provisions did not represent a concrete consensus agreement by those Chinese companies affected. ${ }^{80}$ Just as no distinction truly exists in corporate social responsibility between implicit and explicit rules, hard and soft monikers for corporate governance regulation also melt when seen from the perspective of coordinatability. ${ }^{81}$ The literature takes a costly detour when splitting hairs and trying and describe such law by dividing provisions in endorsing, facilitating,

\footnotetext{
${ }^{77}$ See China Securities Regulatory Commission, Code of Corporate Governance for Listed Companies in China, Zheng Jian Fa No.1 of 2002, 2002, available online.

Code of Corporate Governance

for Listed Companies

${ }^{78}$ For one example, see Buhmann, Karin, Corporate Social Responsibility in China: Current Issues and Their Relevance for Implementation of Law, Copenhagen Journal of Asian Studies 22(1), 2005, available online.

${ }^{79}$ See Cooney, Sean, Making Chinese Labor Law Work: The Prospects for Regulatory Innovation in the People's Republic of China, Fordham International Law Journal 30, 2006, available online.

${ }^{80}$ Lin, Li-Wen, Corporate Social Responsibility in China: Window Dressing or Structural Change, Berkeley Journal of International Law 28, 2010, available online.

${ }^{81}$ Dirk Matten, Dirk and Jeremy Moon, "Implicit" and "Explicit" CSR: A Conceptual Framework for a Comparative Understanding of Corporate Social Responsibility, Academy of Management Review 33(2), 2008, available online.
} 
partnering, mandating, and so forth. ${ }^{82}$ Similar attempts to divide such law as 'internal' and 'external' also miss the point. ${ }^{83}$ Even a cursory look at Figure 14 shows how the concept of coodinatability captures what these other labels miss. Maybe scholars have not seen the "fall of regulation" or the "rise of governance" in analysing Chinese corporate governance. ${ }^{84}$ Maybe coodinatable rules represent those corporate governance rules that represent real regulation in China.

\section{Conclusions}

Should Chinese authorities adopt more hard law when governing corporate interests and behaviour? A long literature exists on the topic - having not come to any consensus and often talking in circles. In this article, we hope to break out of the impasse by describing coodinatable corporate governance rules - concrete, specific, agreeable rules that corporate governance stakeholders (individuals with real interests in these corporations) can agree to. Principles-based or not. Mandatory or not. In a personality-driven system, clarity and tangibility represent the most important attributes of corporate governance rules that individuals follow. Such a focus on coodinatability removes the need to focus on corporate governance benchmarks (like the percent of independent board members or the existence of an audit board). If China's corporate governance rules have not performed as analysts would have hoped (both in the Middle Kingdom and abroad), they should consider looking for existence, nature, and acceptability of coordinatable rules that help, rather than hinder.

\footnotetext{
${ }^{82}$ Ho, Virginia, Beyond Regulation: A Comparative Look at State-Centric Corporate Social Responsibility and the Law in China, Vanderbilt Journal of Transnational Law 46, 2013.

83 Jiang, Fu-xiu and Kenneth Kim, Corporate governance in China: A Modern Perspective, Journal of Corporate Finance 32, 2015, available online.

${ }^{84}$ Lobel, Orly, The Renew Deal: The Fall Of Regulation And The Rise Of Governance In Contemporary Legal Thought, University of San Diego School of Law Legal Studies Research Paper No. 07-27, 2005, available online.
} 